\title{
Environmental Safety and Sustainability: A Panacea for Healthy National Development in Nigeria
}

\author{
Musa Sabo Abdullahi \\ Akpokerie Roseline Ugbede \\ Department of Chemistry, \\ Federal College of Education, \\ Kontagora, Nigeria
}

\section{Doi:10.5901/ajis.2013.v2n13p77}

\begin{abstract}
The role of legislation in inducing responsible attitudes and behaviours towards the environment cannot be overlooked. Legislation serves as an effective instrument for environmental protection, planning, pollution, prevention and control. The following provides a summary of Nigerian legislation on the environment. This paper attempts to discuss environmental problems in Nigeria, characteristic disposal of waste, the consequences of inappropriate disposal, environmental safety as well as its sustainability and protection. Recommendations were also given. One of such recommendations is that environmental protection techniques need to be cultured, home-grown and the framework should begin from "Bottom to Top" and should be community based. The framework should be organized at the village or community level. A numbered of community should be grouped together at the (political) ward level and from ward level to Local Government Level to oversee this function. Environmental protection agents at the local government level should be empowered to punish every offender in form of tax or penalty. Environmental awareness education should be included and enforced in the primary and post primary school curricula.
\end{abstract}

Keywords: Environment, waste disposal, safety, sustainability, protection

\section{Introduction}

The earth is primarily a life support system. It consists essentially of biochemical processes that imbue it with the capacity to sustain life. As an ecosystem, the earth however, has a threshold within which it can effectively absorb or withstand interruptions and radical changes in the biochemical processes that help to sustain life.

Environmental problems and the accelerating changes in living conditions have become a fundamental part of the world in general and metropolises in particular. Earlier, environmental problems have been considered as technical and economic problems; while in the recent decades the social dimensions of environmental problems such as public attention and people's attitudes towards environment have become one of the areas of environmental sociology and environmental psychology (Khalil et al, 2007). Similarly, the developmental activities of man over the decades have primarily restructured the environment and upset the delicate balance of nature. It has resulted in a number of changes on the planet, earth. These changes according to I roha et al (2008) are essentially inimical to the continued existence of man and other life forms on earth.

Globally, the increasing affluence in urban centers, relative to the countryside, has posed problems to the management of the environment (Hardoy and Mitlin, 2001). Urban environments have become the "cesspools" due to increased pollution (air, water, sound and land). The physical correspondence and appearance of different products, and ultimately the waste thereof define the 
state of any environment. The "throw-away" culture is symbolism for fashionableness, 'relevance' and modernity. The attempt of this paper is to show how environmental pollution management has become an issue as a result of advancement of technology, tastes and preferences of the modern society and how the "throw-away culture" (Toffler, 1970) poses a great challenge to environments per se, urban planners and managers especially in the developing countries. Nigeria can be cited as one of the developing countries where environmental pollution has become a fundamental and challenging problem across the country.

The World Health Organization (WHO) refers to waste as "something, which the owner no longer wants at a given time and space and which has no current or perceived market value". This line of thought represented a broad-based approach toward the classification of what constitutes waste. However, what one regards as waste may not be totally useless, as much can be recycled to produce new products. Wastes may be gaseous, liquid, or solid. Whereas gaseous and liquid wastes are free flowing and can easily migrate from one place to another, solid wastes are not free flowing. Handling and containment of liquid and to greater extent solid wastes has remained one of man's intractable problems (Ogbonna et al, 2002).

Nigeria was a country relatively free of environmental problems until late 1990s when it began to experience high rate of population growth. As a result of this population growth, industrialization and modernization, the environmental problems became a serious issue. The rapid increase in population began to use more food with increased by-products, water and its resultant waste, household wastes, remnants of new and renovation of houses which results in uncontrollable amount of environmental pollution. Additionally, urbanization became a great source of contamination of the air, water, land and the environment in general. Development of land, necessary for industrialization, began to violate the country's wildlife habitats. Soil erosion specifically in some parts of the country simultaneously became a prevalent issue, as the country realized the effects of years of agriculture and logging upon the land. All of these potential environmental emergencies came to a head throughout the 1970s and the 1980s, causing a great deal of attention and concern to be cast upon various major problems in need of remedy (Nidal and Zeyad, 2007) This paper attempts to discuss how environmental safety can bring about healthy national development in Nigeria and world at large. The resultant impacts of man's interaction with his environment have enormously contributed to environmental problems facing Nigerian nation. Some of these problems according to Omofonmwan and Osa-Edoh (2008) are urbanization, overpopulation, deforestation, desertification and pollution among others.

\section{Characteristic Disposal of Waste}

Khan (2003) defines solid waste as "material that is cheaper to throw away than to store or use." He goes on to say, nevertheless, that such unwanted material can be segregated, transformed, recycled and re-used with great environmental and financial gain or benefit. In the same strain, it important to note that sources of solid waste are different and this knowledge can be useful in showing that different types of waste are subject to spatial mapping.

Studies on Bamenda City in Cameroon by Achankeng (2003) indicate that one new and increasing element in waste composition is that of non-biodegradable waste. Electronic waste or Ewaste, and waste from foreign goods are increasing. This show how the element of globalization influences wastes generation in the developing world give that the problem transcends across national borders. Lifestyles are linked to various wastes production. From the table it is conspicuous that the nature of waste could produce some benefits especially in agricultural production in the case where urban agriculture is accommodated as part of urban livelihoods and development. The cradle of the throwaway culture, according to Toffler (1970), is the Americas. From America, it has spread to Europe, and in the recent years ultimately globalized.

Toffler (1970) asserts that the philosophy has been perpetrated by the increasing philosophy of socio-cultural transience and transformation. This argument reaches to the notion of 
globalization. He argues that the contemporary society has increased the propensity towards impermanence, modularism, technically innovation and organization. It is based more towards production of goods than any other period in the annals of the history of humanity "not meant to last". This can be seen in aspects like architecture and engineering. In the past, people built to last. New York, according to Toffler has been a "city without history", to exemplify this conception. Technology is ever changing such that obsolescence is on the faster increases than any other time in the past. This brings into perspective the notion of 'fashionableness', which is marked by the basic characteristics of a "...buy, use and throwaway society" (Toffler, 1970). The rise of rentalism and hiring services reinforces the modishness of throwaway and modularism. This explains why the throwaway culture is much more than a simple physical disposal of waste issue. Toffler (1970) typifies the whole phenomenon by citing its dynamics as portrayed by Japan and France. He writes that in Japan, "...throw-away tissues are so widely used that cloth handkerchiefs are regarded as old fashioned, not say unsanitary. And even in France, disposable cigarette lighters are commonplace. From cardboard milk containers to the rockets then power space vehicle, products created for long-term or one-time use are becoming more numerous and crucial to our way of life...But to spread of disposability through the society implies decreased durations in man thing relationships. Instead of being linked with a single object over a relatively long span of time, we are linked for brief periods with the succession of objects that supplant it".

The throwaway culture has critical psychological roots and effects. One effect is that respect to property has changed. Toffler (1970) explains the way the fabric of social experience comprises five relationships. These are people, organizations and ideas and time.

Table1. Five relationships that make up the social experience fabric.

\begin{tabular}{|l|l|}
\hline Component & Description \\
\hline "Things" & A physical setting of natural or man-made objects. \\
\hline 'Place' & A location or arena within which actions occur \\
\hline 'People & Constituents of a social situation \\
\hline 'Organizational Ideas or Information & Network of society \\
\hline 'time & $\begin{array}{l}\text { Point in moment and durations and is the principal } \\
\text { determinant of change }\end{array}$ \\
\hline
\end{tabular}

Source: Adopted from Chirisa (2008).

Table 2. Taxonomy of waste and their sources

\begin{tabular}{|l|l|}
\hline Type of waste & Composition of waste \\
\hline Garbage & $\begin{array}{l}\text { Includes wastes from household preparation, cooking and serving of food; } \\
\text { market refuses, handling, storage and sales of produce and meals. }\end{array}$ \\
\hline $\begin{array}{l}\text { Non-biodegradable } \\
\text { solid waste or rubbish }\end{array}$ & $\begin{array}{l}\text { Paper, carton, cardboard, plastics, clothes, rubber, leather bottles, glass, } \\
\text { ceramics, tin cans, etc }\end{array}$ \\
\hline $\begin{array}{l}\text { Imported second hand } \\
\text { goods from the } \\
\text { developed world }\end{array}$ & $\begin{array}{l}\text { These old goods are near the end of their life cycle and spend little time with } \\
\text { their final owners before being put aside as waste. Cases of accepting imported } \\
\text { foreign waste in exchange for 'hot' currencies have been reported in Africa }\end{array}$ \\
\hline $\begin{array}{l}\text { Electronic waste or E- } \\
\text { waste }\end{array}$ & From white goods are increasing \\
\hline Other sources & $\begin{array}{l}\text { Ashes, bulky waste, street sweeping, abandoned vehicles, nonhazardous } \\
\text { industrial waste, construction and demolition waste etc. Waste derived from } \\
\text { private and public institutions and sewage treatment centres. }\end{array}$ \\
\hline
\end{tabular}

Source: Adopted from Chirisa (2008). 
The "situation" goes with the changing attitudes of "things", which people will assume. Transformation moves with technology, super industrialism and standardization (i.e. uniformitarianism associated with the minimum set values). These are key features indicating that social and economic transformation in society is an irrefutable reality (Chirisa, 2013).

\section{Disposal of Waste and Its Consequence in Nigeria}

Indiscriminate disposal and dumping of waste has become a common practice in Nigerian cities. Most of the waste dumps are located close to residential areas, markets, farms, roadsides, and creeks. The composition of waste dumps; varies widely, with many human activities located close to dump sites. Familiar examples include domestic and industrial wastes. Industrial wastes are generated from industrial activities such as chemicals, pesticides, paints, grease, inorganic materials, oil sludge, and so on. Domestic wastes are those generated from commercial establishments and household activities. They occur in different forms, water-borne waste from households, including sewage and sullage water, rubbish, human and animal remains as well as chemical and laboratory wastes (Ogbonna et al, 2002)

Apart from various diseases and toxic conditions inherent in and derivable from wastes products, the presence of waste degenerates the aesthetic value of the environment. In view of the diverse nature of Nigerian Society and economic, cultural and sociopolitical problems, this paper takes into consideration appropriate strategies and measures that could be adopted for wastemanagement to ensure protection of our environment.

.. According to Izeze (1999), many of the current problems associated with waste disposal have resulted from increasing urban populations, rapid and haphazard industrialization and inevitable increases in waste generation. Many municipal areas generate more solid wastes than they can manage, and this situation tends to increase with income levels and the economic development of the area.

The result of indiscriminate disposal of waste in most cities across Nigeria with the exception of Abuja, the nations' capital, has become a practicing culture of 'use and the throwaway' with no regard to place or its devastating effects humans and the environmental consequence. Some of these attitudes includes indiscriminate dumping of used water sachet, polythene bags, motorcycle or vehicle spare parts, used papers, remains of farm products, household appliances, etc. and eventually find their way into gutters and drainages, and block water way during raining season. This is the cause of most floods in different parts of the country today.

\section{Environmental Safety}

The early1980s witnessed growth of concern for environmental issues in Nigeria particularly at the non-formal level with setting up of the Nigeria Conservation Foundation (NCF). The concern became stronger with the dumping of toxic waste in Koko, a village in Edo State of Nigeria in 1987. As a result, discussions and concern for natural and physical environment, which, used to be treated as esoteric assumed national prominence. Safety and environmental protection are strategic priorities for the Nigerian Government industries, multinational corporations, NonGovernmental organizations and indeed all Nigerians in their respective domains. Keeping the environment healthy and safe wherever we work or do our business is a core value of the every citizenry and the responsibility of the Nigerian government to oversee and monitor the safety of the environment within. Safety and environmental protection should be one of the strategic priorities of the Nigerian government towards a healthy national development of the nation. Nigeria should consider that health, safety and respect for the environment are essentials to the well- being and standard of living of its citizens. 


\section{Sustainability of the Environment}

Although sustainability is still a loosely defined and evolving concept, researchers and policymakers have made tremendous efforts to develop a working paradigm and measurement system for applying this concept in the exploitation, utilization and management of various natural resources. In the past decade, sustainability has increasingly become a key concept and ultimate global for socio-economic development in the modern world. Without any doubt, the sustainable development and management of natural resources fundamentally control the survival and welfare of human society (Omer, 2012).

Sustainability is the destination of sustainable development (Council of Ministers of Education, 2005). I ts aim is to make decision and conduct activities in a manner as to ensure persistence over an apparently indefinite future in the improvement and maintenance of ecosystems, the economy and the health and well-being of people on the earth. The United Nations (1992), Uche (1995), UNESCO (1997) and Inyang $(1998,2001)$ in Iroha et al (2008) observed that education is humanity's best hope and most effective means for the quest to achieve sustainable development at national or global levels. This may be due to the fact that sustainable development calls for particular skills, knowledge, values and attitudes regarding the environment, the economy and the well-being of people. Perhaps, in response to the calls by United Nations Educational, Scientific and Cultural Organization (UNESCO) and United Nations (UN), education for sustainability has become the norm in most countries of the world in recent years.

In Nigeria, there have been some activities aimed at creating awareness and educating the masses on environmental issues. Initially the mass media, various Non- Governmental Organizations (NGOs) and Government Agencies were used to create awareness of the nature of the environment and the need for its sustainability (I roha et al, 2008). A significant point to note here is that if poverty remains at its endemic level across the society, it promotes an unsustainability of whatever infrastructural facilities that is in place. Thus, sustainability can be achieved if government can put a supervisory machinery in place to enforce adherence to regulations and laws governing environmental protection and safety.

\section{Protection of the Environment}

According to Okonko, Ogun, Shittu and Ogunnusi (2009), environmental protection is an integral component of sustainable national development. The environment is threatened in all its abiotic and biotic components: animals, plants, microbes and ecosystems comprising biological diversity; water, soil and air, which form the physical components of habitats and ecosystems; and all the interactions between the components of biodiversity and their sustaining habitats and ecosystems. With the continued increase in the use of chemicals, energy and non-renewable resources by an expanding global population, associated environmental problems will also increase.

The birth of the Nigeria Conservation Foundation (NCF) in the 1980s, the rising interest among policy makers on the need for a sound environmental base for development, the launching of the National Conservation Strategy (NCS) in 1986, the National Resources Conservation Council (NRCC) in 1988, the ultimate launching of the National Policy on the environment in 1989 and the establishment of Federal Environmental Protection Agency (FEPA) in 1988. Hence, in December 1988, as part of the emerging coordinated approach to environmental issues, the agency was established by decree. The coming of FEPA represents a milestone in environmental management effort in Nigeria. The Federal Government of Nigeria in 1988 establish the Federal Environmental Protection Agency (FEPA) (now Federal Ministry of Environment with effect from September, 1999) to protect, restore and preserve the ecosystem of the Federal Republic of Nigeria. The decree 58 of 1988 requires FEPA to establish environmental guidelines and standards for the abatement and control of all forms of pollution and whose mandate was expanded to cover conservation of natural resources and biological diversity (FEPA, 1999). The major function of FEPA is the establishment of 
national environmental guidelines, standards and criteria most especially in the area of water quality, effluent discharge, air and atmospheric quality and including the protection of the ozone layer which in the past was absent (Federal Government of Nigeria, 1988). Others are noise control, hazardous substance discharge control and the removal of wastes and ascertaining spillers' liability. The agency also has power to initiate policy in relation to environmental research and technology and in formulating and implementing policies related to environmental management. In addition, FEPA is given some enforcement powers including the right to inspect facilities and premises, search locations, seize items and arrest people contravening any laws on environmental standards and prosecuting them. The agency is also empowered to initiate specific programmes of environmental protection and may establish monitoring stations or networks to locate sources of and dangers associated with pollution. Furthermore, it has powers to conduct public investigations or enquiries into aspects of pollution (FGN, 1988). FEPA is thus the supreme reference authority in environmental matters in Nigeria although state and local government authorities and institutions including their environmental departments are still expected to play their traditional role of monitoring and enforcing standards as well as fixing penalties, charges, taxes and incentives to achieve certain environmental goals.

Significantly, there are numerous Nigerian environmental laws which seek to conserve, guide, control and manage the exploitation of natural resources, along with the control and prohibition of environmental pollution (FEPA Act, 1990). However, prior to the 1988 Decree (which established FEPA), there were some laws and acts of Government relating to environmental protection. They include; the mineral act of 1969, 1973 and 1984, oil in navigable water Decree of 1968, associated Gas injection act of 1969 and Chad Basin development act of 1973 to mention but a few. These laws and / or acts where promulgated to address specific and identified environmental problems. These were narrow in scope and spatially restricted. Decree No 58 of 1988 as amended by Decree 59 of 1992, which gave birth to the FEPA (Now Ministry of Environment) empower the agency to have control over all issues relating to Nigeria Environment, its resources, exploitation and management. Despite the legal backing and funding, which FEPA enjoys from the federal government, the level of success so far recorded by FEPA is a far cry from her set objectives and goals. This is because the rate of environmental degradation is growing worse than what it was before the establishment of FEPA. For example, urbanization, deforestation, desertification and pollution are now more remarkable than ever before (Omofonmwan and Osa-Edoh 2008).

To this end, the unsustainable exploitation of the environment is blamed on the inability or failure of the environmental laws to correct acts as well as attitudes and beliefs of the different peoples of Nigeria, which impact negatively on the environment and the lack of enforcement of the laws stand out as the most fundamental cause of the inability of the legislations to protect the Niger Delta environment. This is blamed on inadequate funding, corruption, the lack of operational facilities, the low involvement of professionals, the uncooperative attitude of the multinational corporations, and the centralization of legislative powers in the central government, along with the privatization of the Nigerian state.

\section{Recommendations}

Environmental protection techniques need to be cultured, home-grown and the framework should begin from "Bottom to Top" and should be community based. The framework should be organized at the village or community level. A numbered of community should be grouped together at the (political) ward level and from ward level to Local Government Level.

Environmental protection agents at the local government level should be empowered to punish every offenders in form of tax or penalty. Environmental awareness education should be included and enforced in the primary and post primary school curricula.

There is the need for an effective system of public education, to ensure better awareness, appreciation and management of safe environment with regards to the multiple roles of individuals. 
Nigerian government should develop a knowledge and informative package consisting of theoretical, technical and managerial solutions for the treatment and reuse or recycling of waste arising from man's activities.

There is the need to create awareness in environmental sustainability which should be translated into action through sustained environmental education both formal and informal education.

\section{Conclusion}

Environmental safety and its protection is a growing concern world over. Thus, there is the need for an urgent establishment of environmental protection techniques which need to be cultured, home-grown and the framework should begin from "Bottom to Top" and should be community based. The framework should be organized at the village or community level. The local government environmental protection agents should be empowered to enforce environmental laws and administer penalty to offenders. This will bring about safe and healthy environment for sustainable development.

\section{References}

Achankeng E (2003). Globalization, Urbanization and Municipal Solid Waste in Africa, African Studies Association of Australasia and the Pacific Conference Proceedings - African on a Global Stage, http://www.ssn.flinders.edu.au/global/afsaap

Council of Ministers of Education (2005). Educating for Sustainability: The Status of Sustainable Development in Canada. http://www.cmec.Ca/Else/Environment.en.pdf

Chirisa, I. (2013). Solid waste, the Throw-Away' culture and livelihoods: Problems and prospects in Harare, Zimbabwe. J ournal of Environmental Science and Water Resources. 2(1), pp. 001 - 008.

FEPA (1999): National Master Plan for Public Awareness on Environment and Natural Resources conservation in Nigeria, FEPA, Garki, Abuja.

FGN (1988): Federal Environmental Protection Agency Decree 58, 1988, Federal Ministry of Information and Culture, Lagos, Nigeria.

Hardoy, J. E., Mitlin, D. (2001). Environmental problems in an urbanizing world: finding solutions in Africa, Asia, and Latin America. Sterling, VA, Earthscan Publications.

Iroha, K., Uwatt, I. E. and Asim, A. E. (2008). Nigerian Teachers' Attitude Towards Environmental Sustainability Issues in the Curriculum. The Social Sciences. 3(2): 126-131

Inyang-Abia, M. E. (1998). Agenda 21-Based Curriculum Paradigm of R Environmental Education and Sustainable Development in Nigeria. I fe J. Edu. Studies. 5: 252-259.

Inyang-Abia, M. E. (2001). Greening the Science, Technology, Mathematics (STM). Curriculum. A Synthesis for Sustainable Development in Nigeria. West Afr. J. Edu. Res. . 4:81-86.

Izeze I. (1999). Waste management: A solution. The Guardian Newspaper. 18 August, p 41

NEST. (1992). The Challenge of Sustainable Development in Nigeria. Pp.152 -172 An NGO Report Prepared For United Nations Conference on Environment and Development, Rio De Janeiro, Brasil June 1-12.

Ogbonna, D. N., Ekweozor, I. K. E. and Igwe, U. (2002). Waste management: A tool for environmental protection in Nigeria. AMBIO: A J ournal of the Human Environment. Vol. 31 (1), pp. 55-57.

Okonko, I. O., Ogun, A. A., Shittu, O. B. and Ogunnusi, T. A. (2009). Waste

Utilization as a means of Ensuring Environmental Safety - An Overview. EJEAFChe, 8(9), 2009, 836-855. 150 (3): pp 468493.

Omer, A. M. (2012). Sustainable water resources management, future demands and adaptationstrategies in Sudan. Journal of Environmental Science and Water Resources Vol. 1(7), pp. 151 - 168.

Omofonmwan, S. I. and Osa-Edoh, G. I. (2008). The Challenges of Environmental Problems in Nigeria. J. Hum. Ecol., 23(1): 53-57.

Toffler A (1970). Future Shock, Pan Books, London

Uche, S. C. (1995). Education and Sustainable Development: An Introduction In: M. B. Lawal, E. J. Aniah, 
S. C. Uche and I. A. Animashun (Eds). Education for Sustainable Development . Lagos. Macmillan Nigeria Publishers, pp.1.

United Nations Educational, Scientific and Cultural Organization (UNESCO). (1997).

Educating for a Sustainable Future: A Transdisciplinary Vision for Concerted Action. International Conference in Thessaloniki. 